\title{
Potential viral stimulation of primary production observed during experimental determinations of phytoplankton mortality
}

\author{
Michael A. Staniewski ${ }^{1}$, Steven M. Short ${ }^{1,2, *}$ \\ ${ }^{1}$ Department of Ecology and Evolutionary Biology, University of Toronto, 25 Willcocks Street, Toronto, Ontario M5S 3B2, Canada \\ ${ }^{2}$ Department of Biology, University of Toronto Mississauga, 3359 Mississauga Road N, Mississauga, Ontario L5L 1C6, Canada
}

\begin{abstract}
Experimental determinations of phytoplankton growth and mortality were carried out in a freshwater pond in Mississauga, Canada, during May, July, and October 2011. Modified Landry-Hassett-type dilution assays were performed to assess grazing and virus-induced mortality for 4 distinct phytoplankton populations via taxon-specific quantitative polymerase chain reaction (qPCR) assays, and for the entire algal community via fluorometric determination of chlorophyll $a$ (chl a) concentrations. The sources and amounts of mortality observed for the phytoplankton populations varied throughout the year, and often differed from those of the whole community and each other. In several cases, the effects of viruses in the system appeared to counteract the effects of grazing mortality on phytoplankton. In these instances, mortality was greater in the dilution series generated with filtrates that excluded grazers relative to the dilution series created with filtrates that excluded both viruses and grazers. Relative to the grazer-free dilution series, mortality in the virus- and grazer-free dilution series was reduced for the whole community in May by $0.29 \mathrm{~d}^{-1}$, and in July for the Prymnesiales, Chlamydomonadales I, and Chlorellales populations by 0.93, 1.31, and $1.87 \mathrm{~d}^{-1}$, respectively. Although grazing mortality was not observed for the Chlamydomonadales II population during the May experiment, the population's apparent growth rate increased in proportion with the presumed abundance of viruses in the incubation bottles. Our results reinforce the notion that individual phytoplankton taxa can have dynamic roles in aquatic food webs and suggest that viruses can potentially stimulate primary production, counteracting grazing mortality to the point of tipping a phytoplankton population's status from decline to growth.
\end{abstract}

KEY WORDS: Algae - Viruses - Grazers - qPCR · Modified dilution assay - Seasonal · Growth enhancement

Resale or republication not permitted without written consent of the publisher

\section{INTRODUCTION}

Close examination of the interactions between phytoplankton and their grazers and viruses is necessary to fully appreciate the diverse paths of carbon flow through aquatic ecosystems and the factors affecting phytoplankton community composition and succession. Phycologists have long been fascinated by seasonal fluctuations of algae due to contrasting observations of repetitive patterns in some environ- ments and unpredictable patterns elsewhere (Reynolds 2006). Despite intense interest in this topic, complete understanding of the processes that control phytoplankton succession and seasonality, and hence our ability to predict patterns, remains elusive. Changes in algal biomass and community composition have been linked with a wide spectrum of abiotic, seasonally variable factors such as nutrient concentrations, light, temperature, and stratification, to name a few. In fact, recent reports have even high- 
lighted the connection between climate change and altered algal phenology, production, and community structure (Winder \& Sommer 2012). However, early on as research in this area progressed, an imbalance was noted among studies examining factors that influence algal growth versus the few studies that also examined loss processes that could drive algal species succession (Kalff \& Knoechel 1978). Since that time, numerous studies have focused on the importance of the various agents of phytoplankton loss: grazing, viral lysis, programmed cell death, and sinking.

Biologically mediated mortality can be a particularly important component of phytoplankton loss since both viruses and grazers are known to dramatically affect fluxes of energy and nutrients in aquatic food webs (Fuhrman 1999, Wilhelm \& Suttle 1999, Brussaard 2004, Suttle 2007). Thus, to determine the fate of phytoplankton primary production in any environment and fully understand phytoplankton species succession, the sources and amounts of mortality that various phytoplankton groups endure must be quantified. Some studies have examined seasonal variations in the growth and mortality of various phytoplankton groups with respect to either grazing (e.g. Odate \& Imai 2003, Pearce et al. 2008), or grazing and viral lysis (e.g. Personnic et al. 2009), and their results suggest that mortality processes (and grazing pressure in particular) can vary strongly throughout the seasons. However, these studies are relatively rare and are highly variable with respect to the types of algal groups investigated (e.g. communities, size-fraction groups, pigment groups). A common approach for past mortality studies has been the so-called 'dilution method' first introduced by Landry \& Hassett (1982). The theory behind this approach, including its assumptions and limitations, has been thoroughly reviewed and discussed previously (Landry 1993, Kimmance et al. 2007, Kimmance \& Brussaard 2010).

The dilution method was originally developed to estimate grazing rates of marine microzooplankton through the use of bottle incubations of natural (or so-called 'whole') water diluted with grazer- and phytoplankton-free filtrate. Phytoplankton in bottles with greater amounts of diluent were subjected to reduced contact with grazers and so experienced reduced grazing pressure and increased growth rates (Landry \& Hassett 1982, Landry et al. 1995). The bottles were typically incubated over a $24 \mathrm{~h}$ period under ambient environmental conditions, and when net growth rates of phytoplankton from each bottle were plotted against their proportion of filtrate, the resulting linear regression was used to determine grazing rates (the slope of the line) as well as instantaneous growth rates of the phytoplankton in the absence of grazers (the $y$-intercept; Landry 1993, Kimmance \& Brussaard 2010). Once viruses were recognized as ecologically important components of aquatic food webs, it became desirable to estimate their influence on phytoplankton mortality, and a modification was made to the methodology to include an additional parallel dilution series consisting of whole water mixed with grazer- and virus-free filtrate (Evans et al. 2003). Similar to the original dilution assay, increasing the amount of filtrate in the incubation bottles decreased contact between phytoplankton and their grazers and viruses, thus reducing the impact of both agents of mortality. The resulting linear regression provided an estimate of phytoplankton mortality due to both grazing and viral lysis and phytoplankton instantaneous growth rates in the absence of grazers and viruses. As such, the difference between the slopes of the regressions for the 2 parallel dilution series represents the effect of viral lysis alone (Evans et al. 2003, Kimmance \& Brussaard 2010). This method remains very appealing to researchers as it can provide estimates of phytoplankton growth and mortality rates in a single experiment, involves minimal handling or disruption of the organisms being investigated, allows for the analysis of different components of the phytoplankton community (Landry 1993), and can provide a direct measurement of virus-induced mortality rates without the use of many inferred assumptions or conversion factors (Kimmance \& Brussaard 2010).

The continued application of the modified dilution approach has been insightful and has repeatedly shown that the agents of phytoplankton mortality can have a surprising influence on primary producers. One recent study demonstrated that viral lysis can actually enhance or stimulate primary production for certain groups of phytoplankton, presumably through increased nutrient cycling in the lower food web (Weinbauer et al. 2011). Certainly, there is a growing body of evidence demonstrating that virusmediated mortality can stimulate primary or secondary production as non-infected bacteria and phytoplankton assimilate material liberated through viral lysis (Shelford et al. 2012), as was even demonstrated in a much earlier study by Bratbak et al. (1998). These results have important implications for the modified dilution approach, in which viruses are typically considered an additional source of mortality (Fig. 1A). However, the theoretical framework of the method can incorporate viral enhancement of phyto- 


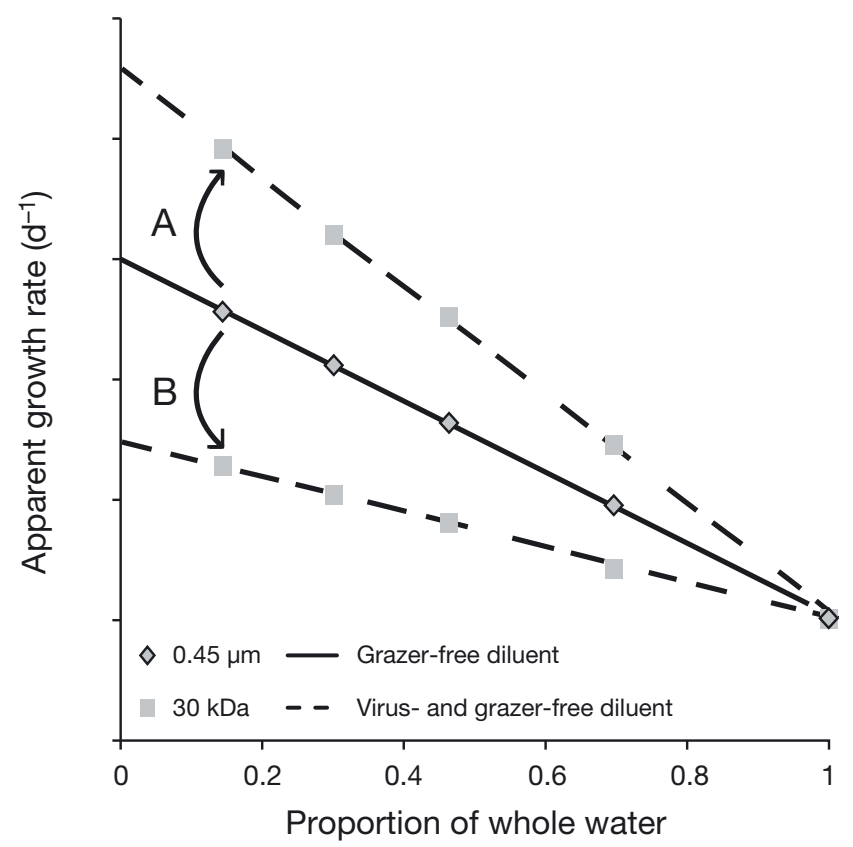

Fig. 1. Idealized dilution plots of apparent growth rate $\left(\mathrm{d}^{-1}\right)$ vs. proportion of whole water. In (A), the observed (net) viral effect is lytic. Viruses are lysing the phytoplankton group of interest, and the mortality coefficient (as derived from the slope) of the grazer- and virus-free diluent series is greater than that of the grazer-free diluent series. Phytoplankton mortality due to grazing and viral lysis is greater than that due to grazing alone. Similarly, the instantaneous growth rate ( $y$-intercept) of phytoplankton in the absence of grazers and viruses is greater than in the absence of grazers alone. In (B), the observed viral effect is stimulatory. Viruses are lysing groups other than the phytoplankton group of interest (which benefits from this lysis), and the mortality coefficient of the grazer- and virus-free series is less than that of the grazer-free series; mortality due to grazing and viral lysis appears less than mortality due to grazing alone. Similarly, the instantaneous growth rate in the absence of grazers and viruses is less than in the absence of grazers alone. Here, phytoplankton growth appears suppressed in the grazerand virus-free series compared to the grazer-free series

plankton growth (Fig. 1B) when the slope of the grazer- and virus-free dilution ( $30 \mathrm{kDa}$ filtrate) series is less negative than the slope of the grazer-free dilution $(0.45 \mu \mathrm{m}$ filtrate) series. In this instance, phytoplankton instantaneous growth is reduced in the absence of viruses, and the rate of mortality due to grazers and viruses appears less than the grazing rate alone. That the modified dilution method has resulted in the observation of viruses stimulating algal growth further demonstrates the method's flexibility and ingenuity.

It is worth noting that several different techniques have been used to determine phytoplankton net growth rates in these dilution assays. These include biomass estimates from chl a concentrations, micro- scopic direct counts (e.g. Landry \& Hassett 1982), flow cytometry (e.g. Baudoux et al. 2006), and high pressure liquid chromatography (e.g. Latasa et al. 1997). However, as mentioned above, the use of these techniques has typically limited the scope of these investigations to examining entire communities, size-fractioned, or pigment-based functional groups. A very recent development in this methodological approach, however, allows for the possibility of determining species-specific rates of growth and mortality during dilution experiments and is based on the use of quantitative polymerase chain reaction (qPCR) assays (Demir et al. 2008, Staniewski et al. 2012). In these experiments, qPCR involves the use of taxon-specific oligonucleotide primers and TaqMan ${ }^{\circledR}$ fluorescent probes to quantify the number of target gene copies in a sample in order to infer changes in phytoplankton species biomass. The utility of this molecular tool in dilution experiments was demonstrated when it was used to contrast the growth, grazing, and viral lysis rates of an entire phytoplankton community as well as 4 distinct constituent populations (Staniewski et al. 2012).

The purpose of the current study was to use the modified dilution method alongside taxon-specific qPCR assays to track seasonal changes in growth and mortality rates for an entire phytoplankton community as well as several distinct phytoplankton populations. To that end, experiments were performed in May, July, and October of 2011 with the aim of assessing whether the individual phytoplankton populations studied had dynamic roles in their environment. In other words, our objective was to determine whether the fate of an individual algal population's production was seasonally variable such that at certain times a population could supply energy to higher trophic levels through grazing, while at other times it more directly fuelled microbial communities through viral lysis.

\section{MATERIALS AND METHODS}

\section{Study site}

Dilution experiments (24 h incubations) were set up on 25 May, 28 July, and 5 October 2011 in a stormwater management pond in Mississauga, Ontario, Canada $\left(43.54598^{\circ} \mathrm{N}, 79.65957^{\circ} \mathrm{W}\right)$, on the University of Toronto Mississauga (UTM) campus. The average depth and surface area of the pond are approximately $1.5 \mathrm{~m}$ and $6000 \mathrm{~m}^{2}$. Water temperature, $\mathrm{pH}$, conductivity, and dissolved oxygen concentration at 
both the surface and bottom of the pond were determined during each dilution experiment using a YSI 600 series sonde and Data Acquisition System (Table 1). Changes in air temperature and total precipitation accumulated over the course of the experiments were determined from archived meteorological data (Environment Canada, http://weather.gc.ca/ canada_e.html).

\section{Dilution experiments}

The dilution experiments were carried out as previously described (Staniewski et al. 2012), with slight modifications to the procedure. Between dilution experiments, all sample containers and incubation bottles were stored with a small amount of $10 \% \mathrm{HCl}$, and prior to use they were rinsed thoroughly, first with $10 \% \mathrm{HCl}$ and then with deionized water. For each dilution experiment, 2 carboys (20 l each) were used to collect surface water from the pond and were immediately transported to the laboratory where all experimental work was performed under dimmed light conditions while attempting to avoid excessive disturbance of the water. All 401 of pond water were initially filtered through $210 \mu \mathrm{m}$ pore-size nylon mesh to remove macroscopic debris. Of this filtered water (hereafter referred to as whole water), 201 were then filtered through $142 \mathrm{~mm}$ diameter, $0.5 \mu \mathrm{m}$ nominal pore-size glass fiber filters (GC-50, Advantec MFS) overlaid onto $142 \mathrm{~mm}$ diameter, $0.45 \mu \mathrm{m}$ pore size membrane filters (HV Durapore, Millipore). Approximately $10 \mathrm{l}$ of the $0.45 \mu \mathrm{m}$ filtrate were then filtered through a 30000 nominal molecular weight

Table 1. Environmental characteristics of the storm-water management pond in which the dilution experiments were performed in 2011. Water temperature (temp), pH, conductivity, and dissolved oxygen concentration (DO) were recorded for each dilution experiment at the surface (depth $\sim 0.03 \mathrm{~m}$ ) and bottom (depth $\sim 1.27 \mathrm{~m}$ ) of the pond. Chlorophyll a concentrations were determined from surface water

\begin{tabular}{|lccccc|}
\hline & $\begin{array}{c}\text { Temp } \\
\left({ }^{\circ} \mathrm{C}\right)\end{array}$ & $\mathrm{pH}$ & $\begin{array}{c}\text { Conductivity } \\
\left(\mathrm{mS} \mathrm{cm}^{-1}\right)\end{array}$ & $\begin{array}{c}\mathrm{DO} \\
\left(\mathrm{mg} \mathrm{l}^{-1}\right)\end{array}$ & $\begin{array}{c}\mathrm{Chl} \mathrm{a} \\
\left(\mu \mathrm{g} \mathrm{l}^{-1}\right)\end{array}$ \\
\hline 25 May & & & & & \\
Surface & 19.22 & 8.09 & 2.91 & 11.44 & 12.68 \\
Bottom & 17.62 & 8.07 & 3.31 & 11.49 & - \\
28 July & & & & & \\
Surface & 25.83 & 7.57 & 1.85 & 11.87 & 10.75 \\
Bottom & 24.38 & 6.94 & 1.21 & 1.02 & - \\
05 October & & & & & \\
$\begin{array}{l}\text { Surface } \\
\text { Bottom }\end{array}$ & 16.89 & 6.76 & 0.74 & 9.50 & 16.16 \\
\hline
\end{tabular}

cut-off (NMWC) Xampler ${ }^{\mathrm{TM}}$ cartridge using a QuixStand $^{\mathrm{TM}}$ ultrafiltration system (GE Healthcare). The filtration apparatuses used in the experiments were thoroughly cleaned with deionized water before and after each dilution experiment. In particular, to ensure filtration efficiency and prevent contamination, the 30000 NMWC ultrafiltration system was cleaned using $\mathrm{NaOH}$ according to the manufacturer's instructions.

For each dilution series, grazer-free $(0.45 \mu \mathrm{m})$ or virus- and grazer-free (30 kDa) filtrate was combined with whole water at the selected proportions $(15,30$, 45 , and $70 \%$ whole water) in order to create $3.31 \mathrm{mix}-$ tures from which $1 \mathrm{l}$ was dispensed into each of 3 polycarbonate incubation bottles (1 1 capacity). Thus, together with triplicate $1 \mathrm{l}$ bottles containing 100\% whole water, a total of 27 incubation bottles were prepared. The bottles were attached in an arbitrary pattern to an anchored floating rack and were incubated on the surface of the UTM storm-water management pond for $24 \mathrm{~h}$. Since the bottles would be floating at or slightly above surface level, neutral density mesh was attached to cover the floating rack during the October dilution experiment to prevent excessive exposure to sunlight (UV radiation), whilst the mesh was not used during the May and July dilution experiments due to overcast conditions. All bottles were kept in the dark during transport to and from the laboratory.

\section{Chlorophyll a determination}

Fluorometric determinations of chlorophyll a (chl a) concentrations were conducted as previously described (Staniewski et al. 2012), based on the approach of Welschmeyer (1994), with the following changes. Glass fiber filters (GF75, Advantec MFS; $25 \mathrm{~mm}$ diameter, $0.3 \mu \mathrm{m}$ nominal pore size) were used during the May and July dilution experiments, but due to supply issues, $1.2 \mu \mathrm{m}$ nominal pore-size glass fiber filters (GF-C, Whatman) were used for the October experiment. In all experiments, $25 \mathrm{ml}$ of sample water were filtered, and filters were extracted in $10 \mathrm{ml}$ of $90 \%$ acetone.

\section{Molecular techniques}

Samples $(50 \mathrm{ml})$ of $210 \mu \mathrm{m}$ filtered whole water were collected from the $100 \%$ whole water bottles at the beginning of each experiment, and $50 \mathrm{ml}$ samples were collected from each of the 27 bottles after incu- 
bation. These $50 \mathrm{ml}$ samples were centrifuged in an Eppendorf A-4-81 swinging bucket rotor at room temperature, $3220 \times g$ for $30 \mathrm{~min}$. The supernatant was decanted by inverting the tubes quickly, and the cell pellets were stored at $-20^{\circ} \mathrm{C}$. Thereafter, DNA extraction from phytoplankton cells was performed as described by Staniewski et al. (2012).

Phytoplankton psbA gene fragments were previously PCR amplified using different $p s b A$ primers (Zeidner et al. 2003, C. M. Short et al. 2011) and reaction conditions (annealing temperatures) in order to increase the diversity of phytoplankton genes amplified (Staniewski et al. 2012). Following electrophoresis and cloning of gel-extracted amplicons using a pGEM-T vector II System (Promega) as previously described (Short \& Short 2008), automated sequencing was performed by the Centre for Applied Genomics at the Hospital for Sick Children (Toronto, ON, Canada). The DNA sequences were edited using BioEdit v.7.0.9 software (Hall 1999), and sequence identity matrix comparisons and phylogenetic analysis were performed to group sequences and identify unique operational taxonomic units (OTUs: sets of sequences less than $97 \%$ identical to any other). As such, in both the study of Staniewski et al. (2012) and the current study, the term 'population' refers to an OTU as defined by a psbA gene sequence.

In an attempt to detect populations that were not observed in the autumn sample collected for the previous study of the UTM pond (Staniewski et al. 2012), PCR amplification, electrophoresis, cloning, and sequencing of $p s b A$ gene fragments was also performed on a water sample from the May 2011 experiment using previously published chlorophytebiased psbA primers (C. M. Short et al. 2011). Quantitative PCR primers and probes were designed for several distinct sequence types (i.e. OTUs) obtained during the study of Staniewski et al. (2012) and the current study using Beacon Designer 7.0 (Premier Biosoft International) with default parameters for TaqMan ${ }^{\circledR}$ probe design. Primers and probes were optimized for highest quality scores and the greatest number of mismatches with non-target sequences. As described by Staniewski et al. (2012), distinct OTUs were discriminated and identified to the level of Order through phylogenetic comparisons using freshwater and marine reference sequences obtained from GenBank. To clarify, these populations represent individual taxa belonging to that Order rather than all taxa within the Order inclusively, and the Order to which each population belongs was used to refer to that population for the sake of accuracy and simplicity. As such, the previously designed quantitative PCR primers and probes for the Prymnesiales, Chlamydomonadales (I), and Chlorellales populations from the study of Staniewski et al. (2012) were used in this study alongside an additional qPCR primer and probe set designed for a psbA sequence from the May 2011 clone library (UP.0511.112, later identified as a second distinct population within the Chlamydomonadales Order). The $5^{\prime}-3^{\prime}$ sequences of the primers and probe for UP.0511.112 are: forward primer: GTA GGA ATC TGG TTC ACA, reverse primer: CAG CCC AAG TGT TTA ATA C, TaqMan ${ }^{\circledR}$ probe: CGT CCG TTA GCG TCT ACT ACA GAT T. All TaqMan ${ }^{\circledR}$ probes were $5^{\prime}$ labeled with FAM (6-carboxyfluorescein) and 3' labeled with Iowa Black ${ }^{\circledR}$ FQ (Integrated DNA Technologies). Amplification efficiencies for all qPCR primer and probe sets were verified to be well within the recommended range (90-110\%) to ensure accurate quantification via the $5^{\prime}$ nuclease assay (Dorak 2006), and the specificity of each primer and probe set was tested as described by Staniewski et al. (2012) and Short \& Short (2009) to ensure that gene copy number estimates from nontarget molecules would be minimally 5 orders of magnitude lower than estimates from the same number of target molecules.

Quantitative PCR was carried out on DNA extracted from the incubation bottles in the 3 dilution experiments as previously described (Staniewski et al. 2012) using an MX3000P qPCR system (Stratagene), with slight modifications to the reactions. The $20 \mu$ reactions contained $2 \mu$ lof $10 \times$ Platinum $^{\circledR}$ Taq buffer (manufacturer-supplied reaction buffer), $5 \mathrm{mM} \mathrm{MgCl}_{2}, 200 \mu \mathrm{M}$ each dNTP, 8 pmol each forward and reverse primer with 4 pmol of probe for all non-Chlorellales reactions and $5 \mathrm{pmol}$ each forward and reverse primer and probe for all Chlorellales reactions (in order to maximize reaction efficiency), $30 \mathrm{nM}$ 1:500 ROX reference dye, 0.5 U Platinum ${ }^{\circledR}$ Taq DNA polymerase (Invitrogen, Life Technologies), and sufficient nuclease-free $\mathrm{H}_{2} \mathrm{O}$ (Integrated DNA Technologies) to achieve a volume of $18 \mu$. The final $2 \mu \mathrm{l}$ consisted of template DNA. For each set of reactions, duplicates of 8 ten-fold serially diluted standards (ranging from $10^{0}$ to $10^{7}$ molecules per reaction) were run. The standards (linear plasmid molecules containing the target $p s b A$ fragment) were prepared as previously described (C. M. Short et al. 2011). As well, triplicate no-template controls containing $2 \mu \mathrm{l}$ of nuclease-free $\mathrm{H}_{2} \mathrm{O}$ (Integrated DNA Technologies) instead of template DNA were run for each set of reactions. 


\section{Data analysis}

Apparent (net) phytoplankton growth rates were calculated for each incubation bottle using the equation $\mu=\ln \left(T_{24} / T_{0}\right) / t$, where $\mu$ is the net observed rate of growth, $T_{24}$ is the estimate of abundance/biomass after the incubation, $T_{0}$ is the estimate of abundance/ biomass immediately before the incubation started, and $t$ is the time interval of incubation ( $1 \mathrm{~d}$; Landry 1993). Initial $T_{0}$ (time zero) abundance/biomass values were averaged and used to calculate the initial abundance/biomass for each of the different dilutions of whole water (Staniewski et al. 2012). For the phytoplankton community, estimates of changes in biomass were inferred from chl a concentrations, whereas relative changes in abundance were estimated for the distinct phytoplankton populations from changes in psbA gene copies as determined via qPCR with taxon-specific primers and probes (Staniewski et al. 2012). Since the efficiency of phytoplankton DNA extraction may have varied between samples due to differences in handling and processing, the qPCR-based abundance estimates (i.e. gene copies) for any given bottle were normalized by dividing the estimated number of gene copies per reaction (i.e. per $2 \mu \mathrm{l}$ template DNA) by the total amount of DNA added to each reaction (i.e. ng per $2 \mu \mathrm{l}$ ). As such, abundance value estimates were expressed in the form of number of target gene copies per nanogram extracted DNA; the use and implications of this correction have been discussed previously (Staniewski et al. 2012).

Linear regression analysis was performed using GraphPad Prism 5 software (see Table 2) which was also used for statistical comparisons between the slopes and intercepts of the $0.45 \mu \mathrm{m}$ and $30 \mathrm{kDa}$ dilution series regressions (see Table 3). An F-test was first used to test the null hypothesis that each regression's slope is equivalent to 0 , and hence, not significant (Zar 1984). A non-significant slope indicates that for a given dilution series, the mortality coefficient should be considered as 0 (i.e. no significant grazing or grazing and viral lysis). An analysis of covariance (ANCOVA) was then performed to test the null hypothesis that for a given experiment the slopes of the 2 dilution series regressions were identical (Zar 1984). Based on the theory underlying the modified dilution method, the effects of viral lysis are observable only if the difference between the slopes of the 2 dilution series regressions is statistically significant ( $p<0.05)$. For those phytoplankton groups that did not have significant differences between the slopes of the dilution series regressions, the null hypothesis that their intercepts are identical was then also tested.
Power analysis was also performed using $\mathrm{G}^{*}$ Power 3.1 (Universität Düsseldorf, Institut für Experimentelle Psychologie) to test the sensitivity of the experimental approach for those groups that did not have a significant difference between the slopes of the dilution series regressions, following the procedure outlined for comparison of 2 independent slopes b1 and b2 (linear bivariate regression: 2 groups, differences between slopes procedure; Faul et al. 2009).

\section{RESULTS}

\section{Environmental parameters}

The environmental characteristics of the stormwater management pond were measured at the time of sample collection on 25 May 2011 (07:08 h), and at the beginning of the incubation period on 28 July 2011 (11:21 h) and 5 October 2011 (12:22 h). These data are presented in Table 1, along with a measurement of the chl a concentration $\left(\mu \mathrm{g} \mathrm{l}^{-1}\right)$ in the water before the incubation period. Over the course of the incubation in May, a total of $17.2 \mathrm{~mm}$ of precipitation was recorded, while air temperature ranged from 8 to $20.9^{\circ} \mathrm{C}$. From 28 to $29 \mathrm{July}, 1.6 \mathrm{~mm}$ of precipitation was recorded, and air temperature ranged from 20.2 to $31.7^{\circ} \mathrm{C}$. No precipitation was recorded over the experimental period in October, and air temperature ranged from 4.8 to $19.3^{\circ} \mathrm{C}$.

\section{Clone library and phylogenetic analysis}

PCR amplification of $p s b A$ gene fragments from the May 2011 experiment ultimately led to 36 clones being sequenced, from which 7 distinct OTUs were observed. Of these OTUs, 1 representative of the dominant group of 27 redundant clone sequences (UP.0511.112, GenBank accession KF444213) was selected for qPCR primer and probe design. Following phylogenetic analysis (data not shown) using neighbor-joining as previously described (Staniewski et al. 2012) as well as maximum parsimony under default conditions in MEGA 4 (Tamura et al. 2007), the population represented by this OTU was identified to the level of Order, for the sake of consistency. The population was found to be a second, distinct species of the order Chlamydomonadales that was most closely related to species of Tetraselmis, based on top GenBank BLAST (Altschul et al. 1990) hits from cultured organisms, and will hereafter be referred to as the Chlamydomonadales II population. 

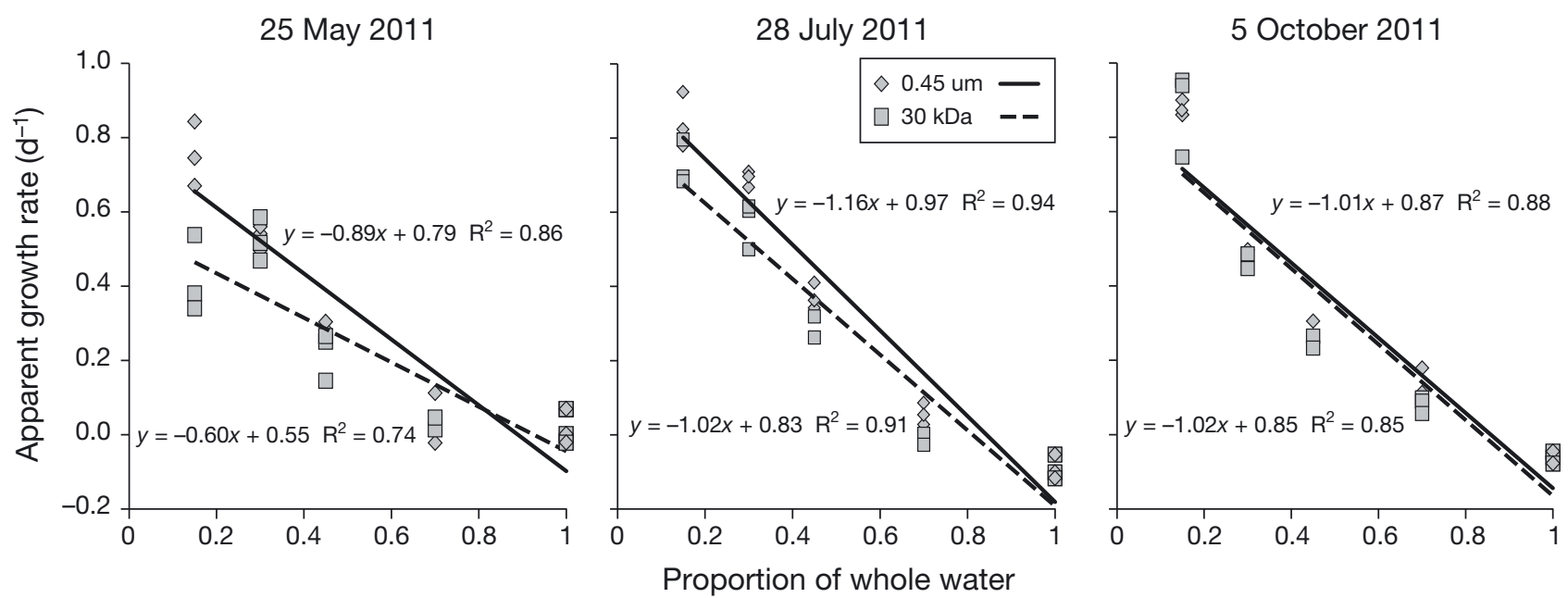

Fig. 2. Dilution plots of apparent growth rate $\left(\mathrm{d}^{-1}\right)$ versus proportion of whole water for the entire phytoplankton community at different times of the year. Each data point represents a single incubation bottle. Equations for the linear regression trend lines of the grazer-free diluent $(0.45 \mu \mathrm{m})$ series and the grazer- and virus-free diluent $(30 \mathrm{kDa})$ series are shown. See Tables $2 \& 3$ for linear regression analysis

\section{qPCR reactions}

For all qPCR reactions, triplicate no-template control reactions were negative (no amplification detected), sample triplicates had acceptable Ct standard deviations (i.e. $<1 \mathrm{Ct}$ ), and reaction efficiency and $\mathrm{r}^{2}$ values from the standard curves were within acceptable ranges (91 to $101 \%$ efficiency, $\mathrm{r}^{2}>0.99$ ). Gene copies of the Prymnesiales and Chlamydomonadales II populations were detectable in the environment in May, July, and October. In the cases of the Chlamydomonadales I and Chlorellales populations, gene copies were only detectable in the environment in July and October.

The range of target gene copies per qPCR reaction (i.e. per $2 \mu \mathrm{l}$ of template DNA) varied considerably between the populations throughout the year. It is worth noting that the number of gene copies per $\mathrm{qPCR}$ reaction is equal to the number of gene copies per $\mathrm{ml}$ of pond water (diluted or undiluted); each reaction contained $1 / 50$ of the total volume of DNA extracted from $50 \mathrm{ml}$ water samples $(2 \mu \mathrm{l}$ of template were used from the $100 \mu \mathrm{l}$ DNA extractions). Examining the pre-incubation $100 \%$ whole water triplicates, the Prymnesiales population was detected at an average of 1007 gene copies in May, 9575 copies in July, and 4971 copies in October. The Chlorellales population was not detected in May, but was detected in July and October at 1715 and 1054 copies, respectively. The Chlamydomonadales II population was detected at 3741 copies in May, 71 copies in July, and 118 copies in October, whereas the Chlamydomonadales I population had the lowest observed number of gene copies per reaction, with an average of only 68 in July and 2 in October. Since the exact number of $p s b A$ genes per cell for these populations is unknown, these ranges should be considered a relative assessment of environmental abundance rather than a direct estimate of biomass (Staniewski et al. 2012).

\section{Phytoplankton growth and mortality rates}

Linear regression trend lines were produced from the plots of apparent growth rate $\left(\mathrm{d}^{-1}\right)$ versus the whole water fraction used for each incubation bottle, for both the entire algal community (Fig. 2) and the 4 individual phytoplankton populations (Fig. 3). Statistical comparisons of the slopes and intercepts of the $0.45 \mu \mathrm{m}$ and $30 \mathrm{kDa}$ dilution series regressions were also performed (Tables $2 \& 3$ ).

In the case of the phytoplankton community, the slopes of all regression lines were significant (i.e. significantly different from 0). During May, the slopes of the $0.45 \mu \mathrm{m}$ and $30 \mathrm{kDa}$ dilution series regressions were significantly different from one another. Mortality due to grazing alone $(0.89 \pm 0.10$ [SE] $\mathrm{d}^{-1}$ ) was observed to be greater than mortality due to grazing in the presence of viral lysis $(0.60 \pm$ $\left.0.10 \mathrm{~d}^{-1}\right)$, so the impact of viruses appeared to decrease algal community mortality by approximately $0.29 \mathrm{~d}^{-1}$. In July, the slopes of the dilution series regressions were not significantly different. 


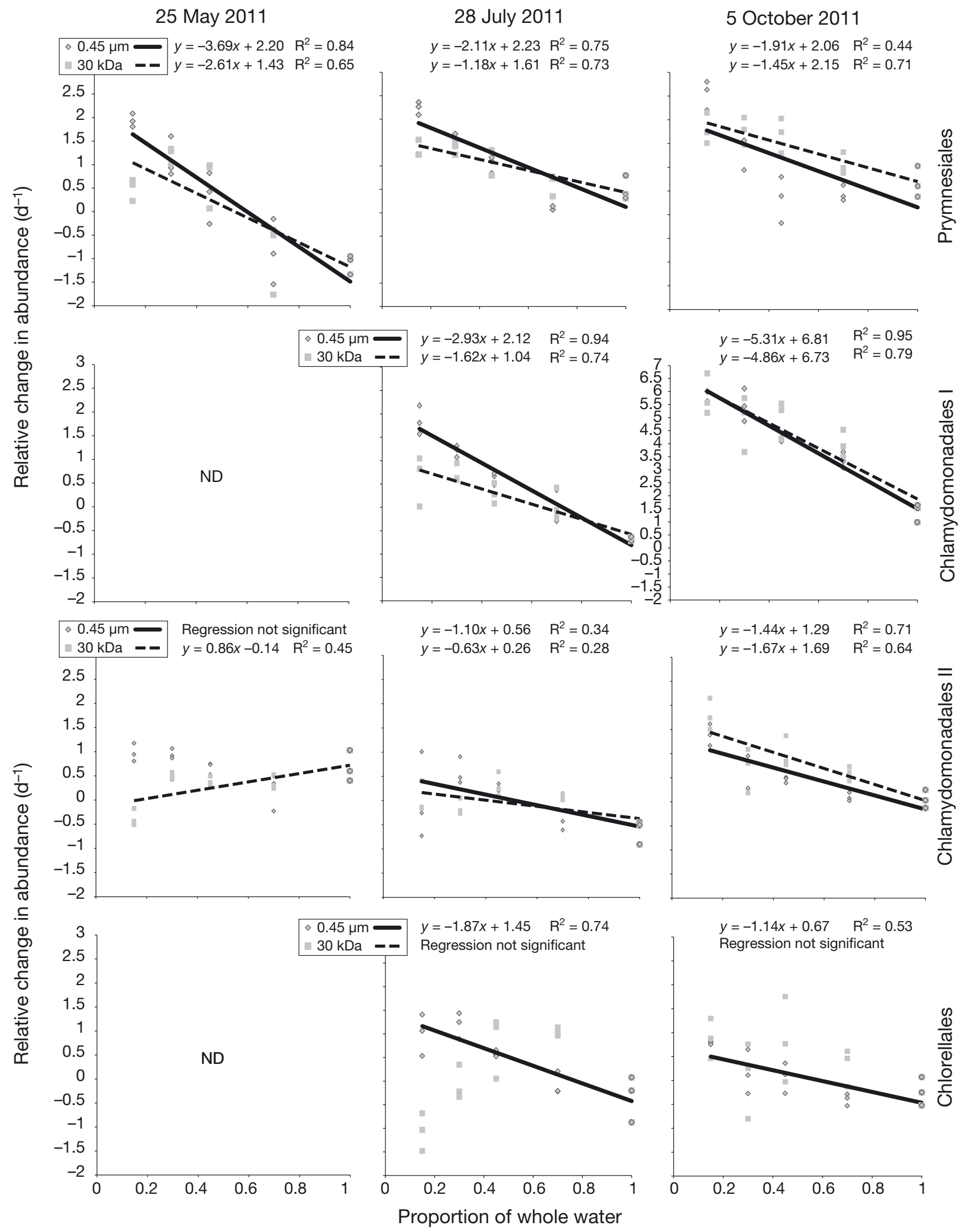

Fig. 3. Dilution plots of relative change in abundance $\left(\mathrm{d}^{-1}\right)$ versus proportion of whole water for 4 distinct phytoplankton populations investigated at different times of the year. These populations are named using the phylogenetic Order to which they belong; however, they represent individual taxa belonging to that Order, rather than all taxa within that Order. Each data point represents a single incubation bottle. ND: not detectable in the environment at that time of year. Where the slope of a linear regression was not significantly different from 0 , neither the trend line nor its corresponding equation were included. See 
As such, grazing was the only significant source of mortality at that time $\left(1.16 \pm 0.08 \mathrm{~d}^{-1}\right)$. Similarly, the slopes and intercepts of the regressions were not significantly different in October for the community, and grazing was once again the only significant source of mortality $\left(1.01 \pm 0.10 \mathrm{~d}^{-1}\right)$. At all times of the year, and in all cases, the rate of mortality was observed to be slightly higher than the growth rate for the community, albeit with considerable overlap in the $95 \%$ confidence intervals and standard error coefficients.

For the Prymnesiales population, the slopes of all the regression lines were significantly non-0. In May and October, neither the slopes nor intercepts of the
$0.45 \mu \mathrm{m}$ and $30 \mathrm{kDa}$ dilution series regressions were significantly different from one another, and so grazing was the only significant source of mortality for the Prymnesiales population in May $\left(3.69 \pm 0.45 \mathrm{~d}^{-1}\right)$ and October $\left(1.91 \pm 0.60 \mathrm{~d}^{-1}\right)$. The rate of growth for the Prymnesiales population was less than the grazing rate in the spring, but greater than the grazing rate in the fall. In July, the slopes of the regressions were significantly different, with mortality due to grazing alone $\left(2.11 \pm 0.34 \mathrm{~d}^{-1}\right)$ being greater than mortality due to grazing in the presence of viral lysis $\left(1.18 \pm 0.20 \mathrm{~d}^{-1}\right)$. Here too, the effects of viruses in the system appeared to decrease mortality for this population by $0.93 \mathrm{~d}^{-1}$, making the rate of mortality in the

Table 2. Linear regression analysis of the $0.45 \mu \mathrm{m}$ and $30 \mathrm{kDa}$ dilution series. Instantaneous growth rates ( $\mu$, $y$-intercept) in the absence of grazers $(0.45 \mu \mathrm{m}$ dilution series) as well as in the absence of grazers and viruses (30 kDa dilution series) are shown, along with the mortality coefficients $(m$, slope) for both grazing $(0.45 \mu \mathrm{m}$ series) and grazing and viral lysis (30 kDa series). The null hypothesis that each regression's slope is 0 was tested using an F-test; $\mathrm{df}_{\mathrm{n}}\left(\mathrm{df}_{\mathrm{d}}\right)$ : degrees of freedom numerator (denominator); ND: not detectable in the environment at that time of year

\begin{tabular}{|c|c|c|c|c|c|c|c|c|c|c|}
\hline & $\begin{array}{c}\text { Dilution } \\
\text { series }\end{array}$ & $\mu\left(\mathrm{d}^{-1}\right) \pm \mathrm{SE}$ & $\mu 95 \% \mathrm{CI}$ & $m\left(^{-1}\right) \pm \mathrm{SE}$ & $m 95 \% \mathrm{CI}$ & $r^{2}$ & $\begin{array}{c}\text { Slope significantly } \\
\text { non-0? }\end{array}$ & $F$ & $\mathrm{df}_{\mathrm{n}}, \mathrm{df}_{\mathrm{d}}$ & $\mathrm{p}$ \\
\hline \multicolumn{11}{|l|}{ Community } \\
\hline \multirow[t]{2}{*}{25 May 2011} & $0.45 \mu \mathrm{m}$ & $0.79 \pm 0.06$ & 0.66 to 0.92 & $-0.89 \pm 0.10$ & -1.10 to -0.67 & 0.86 & Significant & 79.58 & 1,13 & $<0.001$ \\
\hline & 30 kDa & $0.55 \pm 0.06$ & 0.43 to 0.68 & $-0.60 \pm 0.10$ & -0.81 to -0.39 & 0.74 & Significant & 37.72 & 1,13 & $<0.001$ \\
\hline \multirow[t]{2}{*}{28 Jul 2011} & $0.45 \mu \mathrm{m}$ & $0.97 \pm 0.05$ & 0.87 to 1.08 & $-1.16 \pm 0.08$ & -1.33 to -0.98 & 0.94 & Significant & 203.10 & 1,13 & $<0.001$ \\
\hline & 30 kDa & $0.83 \pm 0.05$ & 0.72 to 0.94 & $-1.02 \pm 0.09$ & -1.21 to -0.83 & 0.91 & Significant & 139.00 & 1,13 & $<0.001$ \\
\hline \multirow[t]{2}{*}{05 Oct 2011} & $0.45 \mu \mathrm{m}$ & $0.87 \pm 0.06$ & 0.73 to 1.00 & $-1.01 \pm 0.10$ & -1.23 to -0.79 & 0.88 & Significant & 98.01 & 1,13 & $<0.001$ \\
\hline & 30 kDa & $0.85 \pm 0.07$ & 0.70 to 1.01 & $-1.02 \pm 0.12$ & -1.28 to -0.76 & 0.85 & Significant & 74.13 & 1,13 & $<0.001$ \\
\hline \multicolumn{11}{|l|}{ Prymnesiales } \\
\hline \multirow[t]{2}{*}{25 May 2011} & $0.45 \mu \mathrm{m}$ & $2.20 \pm 0.27$ & 1.61 to 2.78 & $-3.69 \pm 0.45$ & -4.66 to -2.71 & 0.84 & Significant & 66.97 & 1,13 & $<0.001$ \\
\hline & 30 kDa & $1.43 \pm 0.32$ & 0.74 to 2.13 & $-2.61 \pm 0.53$ & -3.77 to -1.46 & 0.65 & Significant & 23.88 & 1,13 & $<0.001$ \\
\hline \multirow[t]{2}{*}{28 Jul 2011} & $0.45 \mu \mathrm{m}$ & $2.23 \pm 0.20$ & 1.79 to 2.67 & $-2.11 \pm 0.34$ & -2.84 to -1.38 & 0.75 & Significant & 38.90 & 1,13 & $<0.001$ \\
\hline & 30 kDa & $1.61 \pm 0.12$ & 1.35 to 1.87 & $-1.18 \pm 0.20$ & -1.61 to -0.74 & 0.73 & Significant & 34.30 & 1,13 & $<0.001$ \\
\hline \multirow[t]{2}{*}{05 Oct 2011} & $0.45 \mu \mathrm{m}$ & $2.06 \pm 0.36$ & 1.28 to 2.84 & $-1.91 \pm 0.60$ & -3.20 to -0.61 & 0.44 & Significant & 10.14 & 1,13 & 0.007 \\
\hline & 30 kDa & $2.15 \pm 0.15$ & 1.82 to 2.48 & $-1.46 \pm 0.26$ & -2.01 to -0.90 & 0.71 & Significant & 32.41 & 1,13 & $<0.001$ \\
\hline \multicolumn{11}{|c|}{ Chlamydomonadales I } \\
\hline \multirow[t]{2}{*}{25 May 2011} & $0.45 \mu \mathrm{m}$ & ND & ND & ND & ND & ND & ND & ND & ND & ND \\
\hline & 30 kDa & ND & ND & ND & ND & ND & ND & ND & ND & ND \\
\hline \multirow[t]{2}{*}{$28 \mathrm{Jul} 2011$} & $0.45 \mu \mathrm{m}$ & $2.12 \pm 0.12$ & 1.86 to 2.38 & $-2.93 \pm 0.20$ & -3.37 to -2.49 & 0.94 & Significant & 207.50 & 1,13 & $<0.001$ \\
\hline & $30 \mathrm{kDa}$ & $1.04 \pm 0.16$ & 0.70 to 1.39 & $-1.62 \pm 0.27$ & -2.20 to -1.05 & 0.74 & Significant & 37.30 & 1,13 & $<0.001$ \\
\hline \multirow[t]{2}{*}{05 Oct 2011} & $0.45 \mu \mathrm{m}$ & $6.81 \pm 0.20$ & 6.38 to 7.25 & $-5.31 \pm 0.34$ & -6.04 to -4.58 & 0.95 & Significant & 248.20 & 1,13 & $<0.001$ \\
\hline & $30 \mathrm{kDa}$ & $6.73 \pm 0.42$ & 5.83 to 7.64 & $-4.86 \pm 0.70$ & -6.36 to -3.36 & 0.79 & Significant & 48.77 & 1,13 & $<0.001$ \\
\hline \multicolumn{11}{|c|}{ Chlamydomonadales II } \\
\hline \multirow[t]{2}{*}{25 May 2011} & $0.45 \mu \mathrm{m}$ & $0.99 \pm 0.17$ & 0.63 to 1.35 & $-0.56 \pm 0.28$ & -1.16 to 0.04 & 0.24 & No & 4.12 & 1,13 & 0.063 \\
\hline & 30 kDa & $-0.14 \pm 0.16$ & -0.49 to 0.20 & $0.86 \pm 0.27$ & 0.29 to 1.44 & 0.45 & Significant & 10.44 & 1,13 & 0.007 \\
\hline \multirow[t]{2}{*}{28 Jul 2011} & $0.45 \mu \mathrm{m}$ & $0.56 \pm 0.26$ & 0.01 to 1.11 & $-1.10 \pm 0.43$ & -2.02 to -0.18 & 0.34 & Significant & 6.66 & 1,13 & 0.023 \\
\hline & 30 kDa & $0.26 \pm 0.17$ & -0.11 to 0.63 & $-0.63 \pm 0.28$ & -1.25 to -0.02 & 0.28 & Significant & 5.02 & 1,13 & 0.043 \\
\hline \multirow[t]{2}{*}{05 Oct 2011} & $0.45 \mu \mathrm{m}$ & $1.29 \pm 0.15$ & 0.95 to 1.62 & $-1.44 \pm 0.26$ & -2.00 to -0.89 & 0.71 & Significant & 31.71 & 1,13 & $<0.001$ \\
\hline & 30 kDa & $1.69 \pm 0.21$ & 1.24 to 2.14 & $-1.67 \pm 0.35$ & -2.42 to -0.92 & 0.64 & Significant & 23.14 & 1,13 & $<0.001$ \\
\hline \multicolumn{11}{|l|}{ Chlorellales } \\
\hline \multirow[t]{2}{*}{25 May 2011} & $0.45 \mu \mathrm{m}$ & ND & ND & ND & ND & ND & ND & ND & ND & ND \\
\hline & 30 kDa & ND & ND & ND & ND & ND & ND & ND & ND & ND \\
\hline \multirow[t]{2}{*}{28 Jul 2011} & $0.45 \mu \mathrm{m}$ & $1.45 \pm 0.18$ & 1.05 to 1.85 & $-1.87 \pm 0.31$ & -2.53 to -1.20 & 0.74 & Significant & 36.85 & 1,13 & $<0.001$ \\
\hline & $30 \mathrm{kDa}$ & $-0.36 \pm 0.45$ & -1.33 to 0.61 & $0.84 \pm 0.75$ & -0.77 to 2.46 & 0.09 & No & 1.27 & 1,13 & 0.281 \\
\hline \multirow{2}{*}{05 Oct 2011} & $0.45 \mu \mathrm{m}$ & $0.67 \pm 0.18$ & 0.28 to 1.06 & $-1.14 \pm 0.30$ & -1.78 to -0.49 & 0.53 & Significant & 14.46 & 1,13 & 0.002 \\
\hline & 30 kDa & $0.89 \pm 0.32$ & 0.20 to 1.60 & $-1.00 \pm 0.54$ & -2.16 to 0.16 & 0.21 & No & 3.48 & 1,13 & 0.085 \\
\hline
\end{tabular}


Table 3. Statistical comparison of the slopes and intercepts of the $0.45 \mu \mathrm{m}$ and $30 \mathrm{kDa}$ dilution series regressions. The null hypothesis that the slopes of the dilution series regressions are identical was tested using an analysis of covariance (ANCOVA). ND: not detectable in the environment at that time of year. For those phytoplankton groups that did not have significant differences between the slopes of the dilution series regressions, the null hypothesis that the intercepts are identical was then tested; $\mathrm{df}_{\mathrm{n}}\left(\mathrm{df}_{\mathrm{d}}\right)$ : degrees of freedom numerator (denominator)

\begin{tabular}{|c|c|c|c|c|c|c|c|c|}
\hline & $\begin{array}{c}\text { Slopes significantly } \\
\text { different? }\end{array}$ & $F$ & $\mathrm{df}_{\mathrm{n}}, \mathrm{df}_{\mathrm{d}}$ & $\underset{\text { (2-tailed) }}{\mathrm{p}}$ & $\begin{array}{l}\text { Intercepts significantly } \\
\text { different? }\end{array}$ & $F$ & $\mathrm{df}_{\mathrm{n}}, \mathrm{df}_{\mathrm{d}}$ & $\underset{\text { (2-tailed) }}{p}$ \\
\hline \multicolumn{9}{|l|}{ Community } \\
\hline 25 May 2011 & Yes & 4.27 & 1,26 & 0.049 & - & - & - & - \\
\hline 28 Jul 2011 & No & 1.30 & 1,26 & 0.264 & Yes & 4.50 & 1,27 & 0.043 \\
\hline 05 Oct 2011 & No & 0.00 & 1,26 & 0.959 & No & 0.13 & 1,27 & 0.724 \\
\hline \multicolumn{9}{|l|}{ Prymnesiales } \\
\hline 25 May 2011 & No & 2.36 & 1,26 & 0.136 & No & 0.92 & 1,27 & 0.347 \\
\hline $28 \mathrm{Jul} 2011$ & Yes & 5.62 & 1,26 & 0.025 & - & - & - & - \\
\hline 05 Oct 2011 & No & 0.48 & 1,26 & 0.494 & No & 2.84 & 1,27 & 0.103 \\
\hline \multicolumn{9}{|c|}{ Chlamydomonadales I } \\
\hline 25 May 2011 & ND & ND & ND & ND & ND & ND & ND & ND \\
\hline $28 \mathrm{Jul} 2011$ & Yes & 15.28 & 1,26 & 0.001 & - & - & - & - \\
\hline 05 Oct 2011 & No & 0.34 & 1,26 & 0.564 & No & 0.46 & 1,27 & 0.504 \\
\hline \multicolumn{9}{|c|}{ Chlamydomonadales II } \\
\hline 25 May 2011 & Yes & 13.73 & 1,26 & 0.001 & - & - & - & - \\
\hline $28 \mathrm{Jul} 2011$ & No & 0.83 & 1,26 & 0.371 & No & 0.15 & 1,27 & 0.701 \\
\hline 05 Oct 2011 & No & 0.27 & 1,26 & 0.607 & Yes & 5.12 & 1,27 & 0.032 \\
\hline \multicolumn{9}{|l|}{ Chlorellales } \\
\hline 25 May 2011 & ND & ND & ND & ND & ND & ND & ND & ND \\
\hline 28 Jul 2011 & Yes & 11.20 & 1,26 & 0.002 & - & - & - & - \\
\hline 05 Oct 2011 & No & 0.05 & 1,26 & 0.831 & No & 2.61 & 1,27 & 0.118 \\
\hline
\end{tabular}

presence of viruses $\left(1.18 \pm 0.20 \mathrm{~d}^{-1}\right)$ considerably lower than the growth rate (either in the absence of grazers $\left[2.23 \pm 0.20 \mathrm{~d}^{-1}\right]$, or grazers and viruses $[1.61$ $\left.\left.\pm 0.12 \mathrm{~d}^{-1}\right]\right)$.

For the Chlamydomonadales I population, with the exception of the spring when the population was not detected in the environment, the slopes of all regressions were significant. In July, the slopes of the $0.45 \mu \mathrm{m}$ and $30 \mathrm{kDa}$ dilution series regressions were significantly different, such that mortality due to grazing in the presence of viral lysis $\left(1.62 \pm 0.27 \mathrm{~d}^{-1}\right)$ was less than mortality due to grazing alone $(2.93 \pm$ $0.20 \mathrm{~d}^{-1}$ ). Once again, the occurrence of viral lysis in the system appeared to decrease mortality for this population by $1.31 \mathrm{~d}^{-1}$. In October, neither the slopes nor intercepts of the dilution series regressions were significantly different, and grazing $\left(5.31 \pm 0.34 \mathrm{~d}^{-1}\right)$ was the only significant source of mortality for that population. It is worth noting that these rates of growth and grazing were the highest observed for any phytoplankton group throughout the year, and that the rate of growth exceeded the grazing rate by a considerable amount.

For the Chlamydomonadales II population, all regression slopes were significantly non-0, with the exception of the population's $0.45 \mu \mathrm{m}$ regression in
May. At that time of year and for that population, grazing was not a significant source of mortality. However, the $30 \mathrm{kDa}$ dilution series regression resulted in a significant positive slope. In July, the slopes and intercepts of the $0.45 \mu \mathrm{m}$ and $30 \mathrm{kDa}$ dilution series regressions were not significantly different, and grazing $\left(1.10 \pm 0.43 \mathrm{~d}^{-1}\right)$ was the only significant source of mortality for that population, and at a higher rate than growth. In October, once again, the slopes of the dilution series regressions were not significantly different, and grazing was the only observed source of mortality $\left(1.44 \pm 0.26 \mathrm{~d}^{-1}\right)$.

The Chlorellales population was not detected in the environment in May, and the slopes of the population's $30 \mathrm{kDa}$ dilution series regressions in July and October were not significantly different from 0 . Since the slopes of the $0.45 \mu \mathrm{m}$ and $30 \mathrm{kDa}$ regressions were significantly different in July, this indicates that grazing was a significant source of mortality $(1.87 \pm$ $0.31 \mathrm{~d}^{-1}$ ); however, when grazing and viral lysis were examined together, no mortality was observable. Hence, the occurrence of viral lysis in the system appeared to decrease Chlorellales mortality by $1.87 \mathrm{~d}^{-1}$. In October, the slopes of the regressions were not significantly different, indicating simply that grazing was the only significant source of mor- 
Table 4. Power analysis examining the sensitivity of the experimental approach for cases where a statistically significant difference between the slopes of the $0.45 \mu \mathrm{m}$ and $30 \mathrm{kDa}$ dilution series regressions was not observed. Using a 2-tailed $t$-test under linear bivariate regression analysis and given $\alpha=0.05$ and the sample sizes used in the experiment, the effect required $\left(\mid \Delta\right.$ slopel $\left._{\text {req }}\right)$ for a desired power of 0.80 was computed and is contrasted here with the observed effect $\left(\mid \Delta\right.$ slopel $\left.\left.\right|_{\text {obs }}\right)$. The SD of the residuals (SD residual $\sigma$ ), $x$-values (proportion of whole water, SD $\sigma \_x$ ), $y$-values (apparent growth rate/relative change in abundance $\left.\mathrm{d}^{-1}, \mathrm{SD} \sigma_{-} y\right)$ and allocation ratio (n2/n1, where $\mathrm{n}$ is the number of samples in a group for comparison) are provided

\begin{tabular}{|c|c|c|c|c|c|c|c|c|}
\hline & Dilution series & Slope & $\mathrm{SD} \sigma \_\mathrm{x}$ & $\mathrm{SD} \sigma \_\mathrm{y}$ & $\mathrm{SD}$ residual $\sigma$ & $\mathrm{n} 2 / \mathrm{n} 1$ & $\mid \Delta$ slopel $_{\text {req }}$ & $\mid \Delta$ slopel $_{\text {obs }}$ \\
\hline \multicolumn{9}{|l|}{ Community } \\
\hline 28 Jul 2011 & $\begin{array}{c}0.45 \mu \mathrm{m} \\
30 \mathrm{kDa}\end{array}$ & $\begin{array}{l}-1.16 \\
-1.02\end{array}$ & $\begin{array}{l}0.31 \\
0.31\end{array}$ & $\begin{array}{l}0.37 \\
0.33\end{array}$ & 0.09 & 1.00 & 0.32 & 0.14 \\
\hline 05 Oct 2011 & $\begin{array}{c}0.45 \mu \mathrm{m} \\
30 \mathrm{kDa}\end{array}$ & $\begin{array}{l}-1.01 \\
-1.02\end{array}$ & $\begin{array}{l}0.31 \\
0.31\end{array}$ & $\begin{array}{l}0.34 \\
0.34\end{array}$ & 0.12 & 1.00 & 0.43 & 0.01 \\
\hline \multicolumn{9}{|l|}{ Prymnesiales } \\
\hline 25 May 2011 & $\begin{array}{c}0.45 \mu \mathrm{m} \\
30 \mathrm{kDa}\end{array}$ & $\begin{array}{l}-3.69 \\
-2.61\end{array}$ & $\begin{array}{l}0.31 \\
0.31\end{array}$ & $\begin{array}{l}1.26 \\
1.01\end{array}$ & 0.56 & 1.00 & 1.89 & 1.08 \\
\hline 05 Oct 2011 & $\begin{array}{l}0.45 \mu \mathrm{m} \\
30 \mathrm{kDa}\end{array}$ & $\begin{array}{l}-1.91 \\
-1.46\end{array}$ & $\begin{array}{l}0.31 \\
0.31\end{array}$ & $\begin{array}{l}0.90 \\
0.54\end{array}$ & 0.52 & 1.00 & 1.76 & 0.45 \\
\hline \multicolumn{9}{|c|}{ Chlamydomonadales I } \\
\hline 05 Oct 2011 & $\begin{array}{c}0.45 \mu \mathrm{m} \\
30 \mathrm{kDa}\end{array}$ & $\begin{array}{l}-5.31 \\
-4.86\end{array}$ & $\begin{array}{l}0.31 \\
0.31\end{array}$ & $\begin{array}{l}1.70 \\
1.70\end{array}$ & 0.61 & 1.00 & 2.10 & 0.45 \\
\hline \multicolumn{9}{|c|}{ Chlamydomonadales II } \\
\hline 28 Jul 2011 & $\begin{array}{c}0.45 \mu \mathrm{m} \\
30 \mathrm{kDa}\end{array}$ & $\begin{array}{l}-1.10 \\
-0.63\end{array}$ & $\begin{array}{l}0.31 \\
0.31\end{array}$ & $\begin{array}{l}0.59 \\
0.37\end{array}$ & 0.41 & 1.00 & 1.39 & 0.47 \\
\hline 05 Oct 2011 & $\begin{array}{c}0.45 \mu \mathrm{m} \\
30 \mathrm{kDa}\end{array}$ & $\begin{array}{l}-1.44 \\
-1.67\end{array}$ & $\begin{array}{l}0.31 \\
0.31\end{array}$ & $\begin{array}{l}0.53 \\
0.65\end{array}$ & 0.34 & 1.00 & 1.17 & 0.22 \\
\hline Chlorellales & & & & & & & & \\
\hline 05 Oct 2011 & $\begin{array}{c}0.45 \mu \mathrm{m} \\
30 \mathrm{kDa}\end{array}$ & $\begin{array}{l}-1.14 \\
-1.00\end{array}$ & $\begin{array}{l}0.31 \\
0.31\end{array}$ & $\begin{array}{l}0.49 \\
0.68\end{array}$ & 0.49 & 1.00 & 1.67 & 0.13 \\
\hline
\end{tabular}

tality for that population at that time $\left(1.14 \pm 0.30 \mathrm{~d}^{-1}\right)$, and at a higher rate than the growth rate.

\section{Power analysis and sensitivity of experimental approach}

For those phytoplankton groups that did not have a statistically significant difference between the slopes of their $0.45 \mu \mathrm{m}$ and $30 \mathrm{kDa}$ dilution series regressions, power analysis was performed to examine the sensitivity of the experimental approach (Table 4). For the phytoplankton community, the effect (difference in slopes between regressions; Steidl et al. 1997) required for a desired power of 0.80 would have to have been $2.3 \times$ the observed effect in July, and $43 \times$ the observed effect in October. For the Prymnesiales population, a desired power of 0.80 would have required $1.75 \times$ the observed effect in May and 3.9 $\times$ the observed effect in October. For the Chlamydomonadales I and Chlorellales populations in October, the required differences needed to be $4.7 \times$ and $12.8 \times$ the observed effect, respectively. Finally, for the Chlamydomonadales II population in July and October, the required differences needed to be $3 \times$ and $5.3 \times$ the observed effect, respectively.

\section{DISCUSSION}

The results of this study demonstrate that individual phytoplankton populations can have dynamic roles in their environment as their growth rates and the sources and amounts of mortality they endure can vary throughout the year. More importantly, our results suggest that the activity of viruses may stimulate phytoplankton growth and counteract grazing mortality. This observation has important consequences for how we interpret the findings of modified dilution experiments. That said, before these results and their broader implications are discussed, the methodological and technical aspects of this study should be considered.

\section{Methodological and experimental considerations}

Nutrient amendments have previously been proposed (Landry et al. 1995) for dilution experiments in order to ensure reasonable estimates of growth and mortality, especially in oligotrophic and nutrient-limited environments; however, such amendments were not included in this study for several reasons. First, it has been argued that such amendments may result in 
unnatural observed growth rates (Kimmance \& Brussaard 2010), and excess nutrients may be detrimental to certain organisms (Landry 1993). Moreover, the physical and chemical parameters of the study environment reflect eutrophic conditions. Most importantly, however, if viral lysis stimulates phytoplankton growth by recycling certain limiting nutrients, such an effect might be masked if those nutrients were added. For these reasons, our study was performed with no nutrient amendments so that growth and mortality estimates could be determined at ambient nutrient concentrations. A parallel series of incubation bottles with amended nutrients could theoretically be added to the experimental design in order to assess these concerns, but doubling the number of samples to be processed and analyzed would certainly increase the handling time for the experiment causing more bottle effects and possibly introducing more experimental noise.

The primary purpose of this study was to develop a deeper understanding of seasonal changes in phytoplankton mortality, in order to assess whether individual phytoplankton taxa have dynamic roles in aquatic food webs. It has already been mentioned that few dilution experiments to date have investigated how patterns of grazing and viral lysis for phytoplankton populations change over time and that the scope of these few investigations has also been variable. Some of these studies performed experiments at different times of the year over a period of several years (e.g. Tijdens et al. 2008), while others repeated experiments several times over a period of a few consecutive months (e.g. Kimmance et al. 2007). Having no expectations of the importance of certain months from previous investigations, and to cover a reasonably broad range of changing environmental parameters, we conducted mortality experiments at approximately 2 mo intervals; at the end of May (Spring) and July (Summer), and at the beginning of October (Fall) in 2011. Given that the results of our study indicate that sources and amounts of mortality can vary considerably for individual phytoplankton populations over a period of $2 \mathrm{mo}$, it may be worthwhile to repeat such experiments in the future on an even finer time-scale to develop a better grasp of the temporal variability in these dynamics.

In regards to the experimental setup, a non-typical triple-replicate 5-dilution fraction scheme (15, 30, 45, 70 , and $100 \%$ whole water) was selected for these assays based on sensitivity and power analysis from a previous study in this environment (Staniewski et al. 2012). Although sensitivity issues with such modified Landry-Hassett style dilution approaches have previ- ously been noted (Kimmance et al. 2007), significant differences between the slopes of the grazer-free and grazer- and virus-free diluent series regressions have been successfully observed several times in studies conducted in this environment (i.e. the current study and Staniewski et al. 2012), as well as in other studies using a 21-bottle incubation scheme (e.g. Evans et al. 2003). That said, when comparing between the 21and 27-bottle incubation schemes, achieved power should not be compared directly, as retrospective power analysis is only effectively used in estimating the effect or sample size necessary for a study to have rejected a particular null hypothesis at a different power level (Steidl et al. 1997). As such, for the taxa that did not have significant differences between the slopes of their regression lines, sensitivity was tested to determine what effect would have been required for a desired power of 0.80 . The differences between the required and observed effect (slopes) for these groups indicate that although this new experimental setup was sufficiently sensitive to identify significant differences for some populations, in the other groups, modifications to the experimental procedure may be unlikely to make a difference (e.g. for the October experiment, the required effect was $43 \times$ the observed effect for the phytoplankton community). Overall, the addition of more incubation bottles into the scheme did not appear to make a considerable difference, and further modifications to the number of bottles seems implausible given the labor-intensive nature of the experimental set-up and processing, and bottlenecks due to logistical constraints (e.g. incubation bottle numbers are limited by long centrifugation times and available centrifuge space, etc.). Moreover, such modifications may be considered unnecessary given that several cases of significant differences between regressions were observed under both schemes.

In regard to the experimental setup, it is also worth considering that since the length of the lytic cycle is variable among different viruses, the duration of any dilution experiment can influence whether measurable cell lysis occurs. For the experiment described here, $24 \mathrm{~h}$ incubations were used to minimize bottle effects, while allowing sufficient time for the replication of most algal viruses whose latent periods are typically less than 24 h (Brussaard \& Martínez 2008). That said, it is possible that viruses with longer latent periods were present in the environment, and their effects on phytoplankton mortality and growth would have been overlooked. With knowledge of an environment's viral community and lengths of lytic cycles for its constituent populations, it would be possible to 
modify the incubation length in future studies to focus on different groups of viruses that may be driving a particular effect (e.g. to test if variations in phytoplankton growth and mortality could be attributed to the rapid lysis of some heterotrophic bacteria, as opposed to algal lysis by viruses with much longer lytic cycles). In any case, during the $24 \mathrm{~h}$ experiments reported here, effects were observed that can be attributed most probably to the presence or absence of viruses in the parallel dilution series.

The $p s b A$ gene was selected as a target gene in this study as $p s b A$-derived taxon-specific qPCR primers and probes had already been developed for several phytoplankton populations observed in the same environment (Staniewski et al. 2012). The gene, which codes for the D1 polypeptide of the photosystem II reaction center complex, was originally selected since it is found in all photosynthetic organisms that carry out oxygenic photosynthesis (Nixon et al.1991), and so the majority of sequences determined from environmental samples targeting this gene should be derived from phytoplankton. Further, $p s b A$ has been shown to be a reasonably good identifier of diverse groups of picophytoplankton, with the additional benefit that it can potentially target both prokaryotic and eukaryotic algae simultaneously (Zeidner et al. 2003). The development of taxon-specific qPCR assays based on other genes is certainly feasible, and it may be a worthwhile future endeavor to contrast rates of growth and mortality for populations using different target genes.

In the current study, centrifugation, rather than filtration, was used to collect phytoplankton cells in order to avoid difficulties associated with quantitatively extracting DNA from cells on filters. Despite the possibility that certain buoyant algae will not centrifuge effectively, the simple fact that DNA was recovered from the populations examined demonstrates that centrifugation was an effective approach for these taxa. There is no reason to expect that the algal populations considered in this study centrifuged with differential efficiency between our various treatments. Since extracting phytoplankton DNA from pelleted cells involves minimal handling, it remains the best strategy for the qPCR approach described in this study.

Finally, it has previously been mentioned that for the phytoplankton community, apparent growth rates were calculated for each incubation bottle from estimates of changes in biomass inferred from changes in chl a concentrations, while apparent growth rate calculations for the individual phytoplankton populations were determined from changes in their relative abundance as inferred from changes in psbA gene copies. As noted above, qPCR-based abundance estimates for each incubation bottle were expressed as target gene copies per nanogram of extracted DNA to correct for variations in DNA extraction efficiencies. The significance of this adjustment has previously been discussed at great length (Staniewski et al. 2012), but overall, this subtle nuance does not affect the patterns of mortality themselves. The patterns of mortality generated from the normalized gene copy data are valid, comparable to each other and to the phytoplankton community as a whole. Further, the values observed for instantaneous growth and mortality rates are comparable among the different populations of phytoplankton that were examined. However, while mortality and growth rate values observed for the individual populations are comparable among themselves, they are not directly comparable to estimates derived for the whole community. Since chl a concentration-based and chloroplast gene copy ( $p s b A)$-based estimates of growth and mortality are derived from different proxy measures of biomass that have different detection limits and sensitivity, it is necessary to interpret the absolute values of growth and mortality cautiously (Staniewski et al. 2012).

\section{Potential viral stimulation of primary production}

One of the most prominent results of this study was the observation of several cases where viral lysis appeared to counteract the effects of grazing on phytoplankton mortality as phytoplankton growth was suppressed for some populations in the virus reduction treatments. For the entire phytoplankton community in May (Fig. 2), and the Prymnesiales, Chlamydomonadales I, and Chlorellales populations in July (Fig. 3), mortality due to grazing alone was significantly higher than mortality due to grazing and viral lysis combined (Table 2).

As previously mentioned, our understanding of viral dynamics in phytoplankton ecology is currently undergoing a paradigm shift with at least 2 recent studies demonstrating that, far from being merely another source of mortality, the activity of viruses can stimulate the growth of certain uninfected populations. Shelford et al. (2012) demonstrated that viral lysis can lead to ammonium production, most probably through the liberation of dissolved organic $\mathrm{N}$ which is remineralized by bacteria, and in turn this pool of recycled $\mathrm{N}$ fuels primary production. Similarly, Weinbauer et al. (2011) demonstrated that the 
growth of Synechococcus can be enhanced by the presence of viruses that lyse heterotrophic bacteria. That paper proposed both direct and indirect means through which viruses could stimulate Synechococcus growth: either indirectly by lysing competitors for inorganic nutrients, or directly through the release of dissolved and particulate organic matter given that the cell debris generated from any lytic event is quickly consumed by both heterotrophic bacteria (Noble \& Fuhrman 1999, Middelboe et al. 2003) and cyanobacteria (Zubkov et al. 2003, Poorvin et al. 2004). Indeed, the observation that viral lysis of phytoplankton can fuel secondary production has been well established (Bratbak et al. 1998). Therefore, it is reasonable to postulate that viral lysis of heterotrophic bacteria, heterotrophic protists, phytoplankton, or even organisms occupying higher trophic levels can stimulate the growth of other phytoplankton either directly through liberation of resources, or indirectly via release from competition.

The method by which such enhancement of phytoplankton growth occurs is beyond the scope of this study given the dilution assay approach used. That said, the results of this study suggest that modified Landry-Hassett-type dilution experiments can potentially detect viral stimulation of primary production for individual populations and/or the phytoplankton community. Though rare, considering the number of dilution experiments that have been performed, precedent for such cases does occur in the literature (e.g. Baudoux et al. 2008, Weinbauer et al. 2011), albeit not using the population-based qPCR approach described here.

Any supposition that the observed phytoplankton growth suppression in the grazer- and virus-free filtrate series was solely the result of viral enhancement ultimately depends on the assumption that the only difference between the 2 filtrates used for the 2 different dilution series was the presence (or absence) of viruses. However, additional possible differences must be considered. In the dilution experiments we describe here, a $0.45 \mu \mathrm{m}$ pore-size filter was used to generate the filtrate for the grazer-free diluent series in order to ensure that larger viruses would not be excluded from these filtrates (as they might have been if a $0.2 \mu \mathrm{m}$ pore-size filter was used). Although early reports of marine heterotrophic activity concluded that only an insignificant amount of activity was due to the $<0.4 \mu \mathrm{m}$ size fraction (Azam \& Hodson 1977), subsequent studies suggested that as much as 20 to $40 \%$ of bacterial activity, inferred from the uptake of labeled substrates, could pass through $0.4 \mu \mathrm{m}$ pore-size filters (Fuhrman 1981). Bacteria were certainly not present in the $30 \mathrm{kDa}$ (grazer- and virus-free) filtrate as it was determined, via epifluorescence microscopy, to be virus-free. Thus, it is possible that more bacteria were present in the grazerfree dilutions compared to the grazer- and virus-free dilutions, and this could have contributed to greater than expected differences in nutrient remineralization and phytoplankton growth between the 2 dilution series. Additionally, previous studies have shown that certain polyethersulfone membrane cartridges used for ultrafiltration may remove (via sorption) a small portion (i.e. $<5 \%$ ) of the filterable (in this case $<30 \mathrm{kDa}$ ) dissolved organic matter (DOM) in water (e.g. Hoffmann et al. 2000). The 30-kDa ultrafiltration cartridge used in the current experiments was a polysulfone membrane, so it is possible that some organic matter was removed not only through filtration, but also through sorption leading to an unintentional reduction of DOM in the grazer- and virus-free dilution series. This loss of DOM may have contributed to the observed suppression of phytoplankton growth in the grazer- and virus-free dilution series when compared to the grazer-free dilution series. All that said, since the dilution series were prepared with varying concentrations of whole and filtered water, small changes in the bacteria or DOM in the filtrates would have been mitigated in the final mixtures with whole water, whereas the presence or absence of viruses in the 2 parallel dilution series remains the most prominent difference between them. For future studies, determinations of bacterial abundance and DOM concentration in the filtrates could help to resolve whether these factors also contribute to differences in phytoplankton growth.

It has previously been proposed that the use of dilution experiments may be problematic for observing cases of viral stimulation due to confounding effects (Weinbauer et al. 2011). Specifically, viral lysis of the phytoplankton community or population of interest (a source of mortality) may occur at the same time as viral lysis of other populations or even organisms occupying other trophic levels (potentially stimulating growth for the population or community of interest) such that the 2 effects are apparently confounding and mask their independent influences on phytoplankton growth. Whilst there is no way to discriminate viral lysis from viral stimulation with the dilution approach (since it is not possible to isolate a single population's viruses using filtration), it can be argued that when the observed effect is large enough, either (net) viral lysis or viral stimulation of a population can be measured using a dilution-based experimental approach. For example, viral lysis was 
observed for both the Chlamydomonadales (currently described as Chlamydomonadales I) and Chlorellales populations in September of 2009 (Staniewski et al. 2012), while in July of 2011, potential virally-enhanced growth was observed for both populations (Fig. 2). Further, even if the confounding effects do occur together (which they may or may not, although we have no way of knowing for certain), the overall effect on the population or community is observable, quantifiable, and ecologically informative. The implications of this are that the modified dilution approach cannot be used to determine absolute viral lysis rates. Instead, all observed viral effects must be considered as the sum of both lytic and stimulatory interactions and therefore henceforth we refer to these effects as the 'net viral effect.'

It may be possible to obtain further information related to the effects of viruses on individual phytoplankton populations by using $\mathrm{qPCR}$ to track changes in the abundance of specific virus populations over the incubation period, and to link these observations to estimates of virus-mediated mortality or virus-mediated growth enhancement. Previous work has already shown that different algal viruses such as prymnesioviruses and chloroviruses occur in the UTM pond (S. M. Short et al. 2011), and taxonspecific qPCR methods have already been developed to monitor algal viruses in freshwater environments (e.g. Short \& Short 2009, C. M. Short et al. 2011, S. M. Short et al. 2011) such that these tools may be an interesting and informative addition for future studies. However, any attempt to link various viral and algal populations would be highly speculative without culture-based verification of specific interactions, and virus isolation and cultivation is itself a nontrivial challenge in aquatic research.

\section{Growth and mortality dynamics}

In May 2011, neither the Chlamydomonadales I nor the Chlorellales populations were detectable in the environment. It has been shown that the use of qPCR is highly desirable as an addition to the modified dilution method since taxon-specific estimates of abundance can be made at low population densities because qPCR has the ability to detect even small numbers of gene copies (Staniewski et al. 2012). This can be seen even in the current study, for example in the case of the Chlamydomonadales I population. Despite the extremely low numbers of gene copies observed for this population at any time of year and the inference that this population was present in the study environment at an extremely low abundance, the population's instantaneous growth and mortality rates were calculated from very small changes and yet a significant difference between the slopes of the regressions for the dilution series was still observed in July (Table 3).

Returning to the May experiment, for the Prymnesiales population, grazing was found to be the only significant source of mortality, suggesting that the carbon fixed by this population was feeding higher trophic levels, and moreover, that the population was declining at the time since the grazing rate was far greater than the population's growth rate. On the other hand, for the phytoplankton community at this same time of year, the effects of viruses appeared to counteract or dampen grazing mortality by approximately one-third. For the Chlamydomonadales II population, the slope of the regression line for the grazer- and virus-free diluent series was positive. Since grazing was not significant for this population at this time of year, the occurrence of viral stimulation of growth would not only dampen mortality, but would instead produce such a pattern where instantaneous growth was proportional to the presumed viral abundance in the incubation bottles. In other words, instantaneous growth rates were greatest in incubation bottles where viruses were the most abundant. It is also interesting that, based on gene copy abundances, the Chlamydomonadales II population was present at its peak abundance at this time of year and yet was not subject to grazing pressure, which it experienced when at lower abundances in July and October. As a possible explanation for this observation, the presence of other more abundant phytoplankton populations (e.g. the Prymnesiales population with $10 \times$ greater gene abundances) may have alleviated grazing pressure on the Chlamydomonadales II population.

In July, the Prymnesiales, Chlamydomonadales I, and Chlorellales populations all appeared to experience enhanced growth as a result of the 'net viral effect,' whereas the phytoplankton community (and the Chlamydomonadales II population) did not. The fact that the phytoplankton community was not enhanced by the 'net viral effect' at this time of year when several constituent populations appeared to be may have been due to the growth and mortality of other populations that were not monitored, especially if these other populations dominated phytoplankton biomass at that time. In that case, we would not expect that the observed patterns of mortality of the few populations monitored would sum to the pattern observed for the community as a whole. In any case, 
viral stimulation of the studied populations' growth had important ecological implications for the activity of these populations. In the case of the Prymnesiales population, the decrease in the rate of mortality due to the apparent activity of viruses $\left(0.93 \mathrm{~d}^{-1}\right)$ was large enough that the rate of mortality $\left(1.18 \pm 0.20 \mathrm{~d}^{-1}\right)$ became lower than the instantaneous growth rate of the population either in the absence of grazers $\left(2.23 \pm 0.20 \mathrm{~d}^{-1}\right)$ or grazers and viruses $\left(1.61 \pm 0.12 \mathrm{~d}^{-1}\right)$. If considered on its own, the grazing rate $(2.11 \pm$ $0.34 \mathrm{~d}^{-1}$ ) would have exceeded the instantaneous growth of the population in the absence of grazers and viruses. However, the apparent stimulatory effects of viruses appeared to tip the population from decline to successful growth. In the most extreme case, for the Chlorellales population, the effects of viruses seemed to counteract the effects of grazing mortality, such that there was no observable signal of mortality from the combined virus and grazer reduction treatment, as evident from the non-significant regression of the relative changes in abundance for this dilution series. The shape of the non-significant regression (i.e. the $30 \mathrm{kDa}$ dilution series) appears to be non-linear for this population at this time of year. Within the framework of dilution-based mortality experiments, mortality cannot be inferred from nonlinear growth responses to dilution; thus, these results need to be interpreted cautiously. Nevertheless, differences in the activity of viruses between the dilution series is a plausible explanation for the fact that mortality was detected in the $0.45 \mu \mathrm{m}$ series, but not the $30 \mathrm{kDa}$. Overall, the effects of viruses in the system at this time of year appeared to stimulate the growth and success of several phytoplankton populations. Given that so many of the populations investigated appeared to benefit from the lysis of other, infected populations, we can also potentially infer that a great deal of energy was being shunted into pools of dissolved and particulate organic matter at this time.

In October, grazing was found to be the only significant source of mortality (albeit at different rates) for the phytoplankton community, the Prymnesiales, Chlamydomonadales I, Chlamydomonadales II, and Chlorellales populations, suggesting again that the carbon fixed by these primary producers was being used to feed higher trophic levels rather than dissolved and particulate pools, had they experienced direct mortality due to viral lysis. In spite of the grazing pressure, some of the populations were successfully growing (e.g. Prymnesiales, Chlamydomonadales I) while others were declining (e.g. Chlorellales) at this time of year. It is interesting that the
Chlamydomonadales I population experienced the highest grazing and growth rates among the populations (2 to 3 times higher), particularly given its supposed low abundance (based on the number of gene copies observed during the qPCR reactions). This certainly reinforces the widely accepted view that a population's rates of growth and mortality (turnover) can be more ecologically important than its biomass.

\section{CONCLUSIONS}

The results of this study demonstrate that throughout the year, individual phytoplankton taxa and the community as a whole have dynamic growth rates, and sources and amounts of mortality. Moreover, they suggest that 'net viral effects' that lead to an apparent stimulation of phytoplankton growth by viruses can also change over time. Ultimately the growth and mortality dynamics observed during this study highlight the seasonally variable roles individual phytoplankton, and even whole phytoplankton communities, play in aquatic food webs. In particular, it is possible that the 'net viral effect' of stimulating a phytoplankton population's growth through the lysis of co-occurring phytoplankton, bacteria, or perhaps even heterotrophic protists can counteract grazing mortality and tip the balance from a population's decline to its success.

Given that the concept of viral stimulation or 'trickle-up' effects is relatively novel and only now beginning to be investigated thoroughly, it is important that it be regarded critically in order to assure that such effects are biologically relevant and not merely methodological artefacts. The use of these modified dilution assays, and in particular the addition of qPCR to track taxon-specific rates of growth and mortality can potentially provide a convincing means of addressing such issues. Although there may be a few potential differences between the treatments as discussed above, the most prominent difference between the sets of treatments in these experiments is the presence or absence of viruses in the filtrate. Further, considering that observations for all these various taxa are derived from the same incubation bottles, and that we consistently observe markedly different outcomes for different populations within the same incubation bottles, the argument that the results from this study are mere experimental artefacts is not well supported. Experimental artefacts stemming from the experimental design or set-up would necessarily affect all taxa in the same bottles in the same way. Other studies have demon- 
strated viral stimulation of growth through viral reduction and recovery experiments (e.g. Weinbauer et al. 2011), but based on the experimental design and the conceptual framework of the dilution method, we can be reasonably satisfied with observations of apparent viral stimulation, especially when they occur across taxa, experiments, and time. Moreover, the acknowledgment that viral effects on a population of interest may be both lytic and stimulatory necessitates that any observations we derive from modified dilution experiments be considered 'net viral effects.'

These findings therefore contribute to the paradigm shift now occurring in which, rather than seeing the activity of viruses as being merely parasitic and mortality-inducing, when we take a step back and examine their activity from a system-based perspective, we see that they are frequently essential components of aquatic ecosystems that drive the flow of energy and can stimulate growth for the uninfected constituent populations. The difference between ecological malevolence and benevolence may simply be a matter of scale.

Acknowledgements. This research was supported in part by the Canadian Foundation for Innovation Leaders Opportunity Fund and NSERC Discovery grants awarded to S.M.S. as well as NSERC and OGS scholarships awarded to M.A.S.

\section{LITERATURE CITED}

Altschul SF, Gish W, Miller W, Myers EW, Lipman DJ (1990) Basic local alignment search tool. J Mol Biol 215:403-410

- Azam F, Hodson RE (1977) Size distribution and activity of marine heterotrophs. Limnol Oceanogr 22:492-501

Baudoux AC, Noordeloos AAM, Veldhuis MJW, Brussaard CPD (2006) Virally induced mortality of Phaeocystis globosa during two spring blooms in temperate coastal waters. Aquat Microb Ecol 44:207-217

Baudoux AC, Veldhuis MJW, Noordeloos AAM, van Noort G, Brussaard CPD (2008) Estimates of virus- vs. grazing induced mortality of picophytoplankton in the North Sea during summer. Aquat Microb Ecol 52:69-82

Bratbak G, Jacobsen A, Heldal M (1998) Viral lysis of Phaeocystis pouchetii and bacterial secondary production. Aquat Microb Ecol 16:11-16

Brussaard CPD (2004) Viral control of phytoplankton populations - a review. J Eukaryot Microbiol 51:125-138

Brussaard CPD, Martínez JM (2008) Algal bloom viruses. Plant Viruses 2:1-13

> Demir E, Coyne KJ, Doblin MA, Handy SM, Hutchins DA (2008) Assessment of microzooplankton grazing on Heterosigma akashiwo using a species-specific approach combining quantitative real-time PCR (qPCR) and dilution methods. Microb Ecol 55:583-594

Dorak MT (ed) (2006) Real-time PCR. Taylor \& Francis Group, New York, NY
Evans C, Archer SD, Jacquet S, Wilson WH (2003) Direct estimates of the contribution of viral lysis and microzooplankton grazing to the decline of a Micromonas spp. population. Aquat Microb Ecol 30:207-219

> Faul F, Erdfelder E, Buchner A, Lang AG (2009) Statistical power analyses using $\mathrm{G}^{*}$ Power 3.1 : tests for correlation and regression analyses. Behav Res Methods 41: 1149-1160

Fuhrman JA (1981) Influence of method on the apparent size distribution of bacterioplankton cells: epifluorescence microscopy compared to scanning electron microscopy. Mar Ecol Prog Ser 5:103-106

Fuhrman JA (1999) Marine viruses and their biogeochemical and ecological effects. Nature 399:541-548

Hall TA (1999) BioEdit: a user-friendly biological sequence alignment editor and analysis program for Windows 95/98/NT. Nucleic Acids Symp Ser (Oxf) 41:95-98

Hoffmann SR, Shafer MM, Babiarz CL, Armstrong DE (2000) A critical evaluation of tangential-flow ultrafiltration for trace metal studies in freshwater systems. 1. Organic carbon. Environ Sci Technol 34:3420-3427

Kalff J, Knoechel R (1978) Phytoplankton and their dynamics in oligotrophic and eutrophic lakes. Annu Rev Ecol Syst 9:475-495

Kimmance SA, Brussaard CPD (2010) Estimation of viralinduced phytoplankton mortality using the modified dilution method. In: Wilhelm SW, Weinbauer MG, Suttle CA (eds) Manual of aquatic viral ecology. American Society of Limnology and Oceanography, Waco, TX, p 65-73

$>$ Kimmance SA, Wilson WH, Archer SD (2007) Modified dilution technique to estimate viral versus grazing mortality of phytoplankton: limitations associated with method sensitivity in natural waters. Aquat Microb Ecol 49: 207-222

Landry MR (1993) Estimating rates of growth and grazing mortality of phytoplankton by the dilution method. In: Kemp PF, Sherr BF, Sherr EB, Cole JJ (eds) Handbook of methods in aquatic microbial ecology. Lewis Publishers, Boca Raton, FL, p 715-722

> Landry MR, Hassett RP (1982) Estimating the grazing impact of marine micro-zooplankton. Mar Biol 67:283-288

> Landry MR, Kirshtein J, Constantinou J (1995) A refined dilution technique for measuring the community grazing impact of microzooplankton, with experimental tests in the central equatorial Pacific. Mar Ecol Prog Ser 120: 53-63

- Latasa M, Landry MR, Schlüter L, Bidigare RR (1997) Pigment specific growth and grazing rates of phytoplankton in the central equatorial Pacific. Limnol Oceanogr 42: 289-298

> Middelboe M, Riemann L, Steward GF, Hansen V, Nybroe O (2003) Virus-induced transfer of organic carbon between marine bacteria in a model community. Aquat Microb Ecol 33:1-10

> Nixon PJ, Rogner M, Diner BA (1991) Expression of a higher plant psbA gene in Synechocystis 6803 yields a functional hybrid photosystem II reaction center complex. Plant Cell 3:383-395

Noble RT, Furhman JA (1999) Breakdown and microbial uptake of marine viruses and other lysis products. Aquat Microb Ecol 20:1-11

Odate T, Imai K (2003) Seasonal variation in chlorophyllspecific growth and microzooplankton grazing of phytoplankton in Japanese coastal water. J Plankton Res 25: 1497-1505 
Pearce I, Davidson AT, Wright S, van den Enden R (2008) Seasonal changes in phytoplankton growth and microzooplankton grazing at an Antarctic coastal site. Aquat Microb Ecol 50:157-167

Personnic S, Domaizon I, Sime-Ngando T, Jacquet S (2009) Seasonal variations of microbial abundances and virus- versus flagellate-induced mortality of picoplankton in three peri-alpine lakes. J Plankton Res 31: 1161-1177

Poorvin L, Rinta-Kanto JM, Hutchins DA, Wilhelm SW (2004) Viral release of iron and its bioavailability to marine plankton. Limnol Oceanogr 49:1734-1741

Reynolds CS (2006) The ecology of phytoplankton. Cambridge University Press, New York, NY

Shelford EJ, Middelboe M, Møller EF, Suttle CA (2012) Virus-driven nitrogen cycling enhances phytoplankton growth. Aquat Microb Ecol 66:41-46

Short CM, Rusanova O, Short SM (2011) Quantification of virus genes provides evidence for seed-bank populations of phycodnaviruses in Lake Ontario, Canada. ISME J 5: 810-821

Short SM, Short CM (2008) Diversity of algal viruses in various North American freshwater environments. Aquat Microb Ecol 51:13-21

Short SM, Short CM (2009) Quantitative PCR reveals transient and persistent algal viruses in Lake Ontario, Canada. Environ Microbiol 11:2639-2648

Short SM, Rusanova O, Staniewski MA (2011) Novel phycodnavirus genes amplified from Canadian freshwater environments. Aquat Microb Ecol 63:61-67

Staniewski MA, Short CM, Short SM (2012) Contrasting community versus population-based estimates of grazing and virus-induced mortality of phytoplankton. Microb Ecol 64:25-38

Editorial responsibility: Gunnar Bratbak, Bergen, Norway
Steidl RJ, Hayes JP, Schauber E (1997) Statistical power analysis in wildlife research. J Wildl Manag 61:270-279

Suttle CA (2007) Marine viruses-major players in the global ecosystem. Nat Rev Microbiol 5:801-812

- Tamura K, Dudley J, Nei M, Kumar S (2007) MEGA4: Molecular Evolutionary Genetics Analysis (MEGA) software version 4.0. Mol Biol Evol 24:1596-1599

> Tijdens M, Van De Waal D, Slovackova H, Hoogveld HL, Gons HJ (2008) Estimates of bacterial and phytoplankton mortality caused by viral lysis and microzooplankton grazing in a shallow lake. Freshw Biol 53: 1126-1141

> Weinbauer MG, Bonilla-Findji O, Chan AM, Dolan JR and others (2011) Synechococcus growth in the ocean may depend on the lysis of heterotrophic bacteria. J Plankton Res 33:1465-1476

> Welschmeyer NA (1994) Fluorometric analysis of chlorophyll $a$ in the presence of chlorophyll $b$ and pheopigments. Limnol Oceanogr 39:1985-1992

$>$ Wilhelm SW, Suttle CA (1999) Viruses and nutrient cycles in the sea. BioScience 49:781-788

> Winder M, Sommer U (2012) Phytoplankton response to a changing climate. Hydrobiologia 698:5-16

Zar JH (1984) Biostatistical analysis, 2nd edn. Prentice-Hall, Upper Saddle River, NJ

Zeidner G, Preston CM, Delong EF, Massana R, Post AF, Scanlan DJ, Beja O (2003) Molecular diversity among marine picophytoplankton as revealed by psbA analyses. Environ Microbiol 5:212-216

Zubkov MV, Fuchs BM, Tarran GA, Burkhill PH, Amann R (2003) High rate of uptake of organic nitrogen compounds by Prochlorococcus cyanobacteria as a key to their dominance in oligotrophic waters. Appl Environ Microbiol 69:1299-1304

Submitted: August 5, 2013; Accepted: November 4, 2013 Proofs received from author(s): January 17, 2014 